ISSN 1678-3921

Journal homepage: www.embrapa.br/pab

For manuscript submission and journal contents, access: www.scielo.br/pab

\section{Productivity and beverage sensory quality of arabica coffee intercropped with timber species}

\begin{abstract}
The objective of this work was to evaluate the productivity and beverage sensory quality of arabica coffee under the influence of tree species cultivated at different spacings. The experiment was set in 2012, in the municipality of Santo Antônio do Amparo, in the state of Minas Gerais, Brazil. A randomized complete block design was carried out with four replicates and seven treatments, as follows: Catuaí Vermelho IAC 99 Coffea arabica in monoculture $(3.40 \times 0.65 \mathrm{~m})$; and this cultivar intercropped at two spacings (9.0x13.6 and 18.0x13.6 m) in the coffee row - either with African mahogany (Khaya ivorensis), teak (Tectona grandis), or pink cedar (Acrocarpus fraxinifolius). Three coffee rows were fixed between rows, totaling 13.6 $\mathrm{m}$ between the wooded rows. Productivity, sensory analysis (cup test), and content analysis of sensory attributes were evaluated in the 2017 and 2018 crop years. The treatments and years of harvest influenced productivity. The sensory analysis was positive for coffee intercropped with African mahogany and teak, in 2018. Sensory attributes and nuances are modified by the years of harvest. Arabica coffee plants intercropped with African mahogany show a superior productivity, regardless of the spacing between species, as well as a higher sensory quality in the 2018 harvest.
\end{abstract}

Index terms: Acrocarpus fraxinifolius, Coffea arabica, Khaya ivorensis, Tectona grandis, agroforestry system.

\section{Produtividade e qualidade sensorial da bebida de café arábica em consórcio com espécies madeireiras}

Resumo - O objetivo deste trabalho foi avaliar a produtividade e a qualidade sensorial da bebida do café arábica sob a influência de espécies arbóreas cultivadas em diferentes espaçamentos. O ensaio foi instalado em 2012, no município do Santo Antônio do Amparo, no estado de Minas Gerais, Brasil. Um delineamento de blocos ao acaso foi realizado, com quatro repetições e sete tratamentos, conforme a seguir: Coffea arabica Catuaí Vermelho IAC 99 em monocultivo $(3,40 \times 0,65 \mathrm{~m})$; e essa cultivar consorciada em dois espaçamentos (9,0x13,6 e 18,0x13,6 m), na linha dos cafeeiros, com mogno-africano (Khaya ivorensis), teca (Tectona grandis), ou cedro-rosa (Acrocarpus fraxinifolius). Nas entrelinhas, foram fixadas três linhas de café, tendo totalizado 13,6 m entre as fileiras arborizadas. A produtividade, a análise sensorial (prova de xícara) e a análise de conteúdo dos atributos sensoriais foram avaliadas nas safras de 2017 e 2018. Os tratamentos e os anos de colheita influenciaram na produtividade. A análise sensorial foi positiva para o consórcio com o mogno-africano e a teca, em 2018. Os atributos sensoriais e as nuances são modificados pelos anos de colheita. Os cafeeiros arábica consorciados com mogno-africano apresentam produtividade superior, independentemente 
do espaçamento entre as espécies, bem como qualidade sensorial superior na colheita de 2018.

Termos para indexação: Acrocarpus fraxinifolius, Coffea arabica, Khaya ivorensis, Tectona grandis, sistema agroflorestal.

\section{Introduction}

Agroforestry systems increase the versatility of agriculture, besides enabling the productive diversification (Schembergue et al., 2017). Therefore, the adoption of adaptation strategies for climate change can increase the potential of Brazilian agriculture (Cunha et al., 2015).

The species of the selected tree or its spatial arrangements within intercropped systems result in different microclimate changes (Araújo et al., 2015), which means that the insertion of the "key" species to the system may be promising for coffee productivity. The identification of the most appropriate wood species has been aimed at the production of coffee beans with higher quality in intercropping systems (Souza et al., 2019).

Currently, the encouragement for the lumber industry of high commercial value with the species African mahogany (Khaya ivorensis A. Chev.), teak (Tectona grandis L. f.), and pink cedar (Acrocarpus fraxinifolius Wight \& Arn) in coffee (Coffea arabica L.) cultivations may result in a higher long-term net income (Suatunce et al., 2009), besides allowing of a higher sustainability period of the system.

The species to be added to the system is very important, thus, the forest management is essential to avoid affecting the main crop due to excessive shade. Too much shade results in loss of coffee productivity and quality. According to Valencia et al. (2016), the coffee beverage may be enhanced under partial shading, when intercropped with tree species.

The importance of environmental issues linked to the producer's source of extra income and the increase of productivity, in addition to the customer's satisfaction about coffee quality, are standard aspects that shape the segmentation strategies of the coffee market in Brazil, and are therefore being strongly enhanced.

There is a great demand for knowledge on the productivity and quality of intercropped coffee; even though, there is a lack of consolidated information about the planting arrangements that allow of a better feasible performance of such system nowadays.

The objective of this work was to evaluate the productivity and sensory quality of arabica coffee, in the 2017 and 2018 crop years, under the influence of tree species at different spacing arrangements.

\section{Materials and Methods}

The experiment was set in November 2012, in the Lagoa Farm, owned by the Neumann Kaffee Gruppe (NKG), in the municipality of Santo Antônio do Amparo, in the state of Minas Gerais, Brazil. This is a coffee producing region in southern Minas Gerais, whose coordinates are $20^{\circ} 54^{\prime} 58.1^{\prime \prime} \mathrm{S}$ and $44^{\circ} 51^{\prime} 13.7^{\prime \prime} \mathrm{W}$, at $1,089 \mathrm{~m}$ altitude, with $19.8^{\circ} \mathrm{C}$ mean annual temperature and 1,670 $\mathrm{mm}$ annual rainfall. According to the Köppen-Geiger's classification, the climate of the region is Cwa (subtropical highland climate), with dry winter and hot summer.

The soils of the area have been classified as Latossolos (Santos et al., 2018), i.e., Oxisol. In 2017 and 2018 harvests, the productivity and beverage quality were evaluated.

The experiment was carried out using a randomized block design, consisting of four replicates, in plots subdivided over time. Seven treatments were performed, one with Catuaí Vermelho IAC 99 arabica coffee cultivar in monoculture (Mono); and the other treatments with this cultivar intercropped with three species, in two spacings, as follows: African mahogany, at 9.0x13.6 m (MoE1) spacing; African mahogany, at 18.0x13.6 m (MoE2) spacing; teak, at 9.0x13.6 m (TeE1) spacing; teak, at 18.0x13.6 m (TeE2) spacing; pink cedar, at 9.0x13.6 m (AcE1) spacing; and with pink cedar, at of 18.0x13.6 m (AcE2) spacing.

The three wood plant species were planted in the coffee rows. Simultaneously, Catuaí Vermelho IAC 99 arabica coffee cultivar was planted at $3.40 \mathrm{~m}$ spacing between rows, and $0.65 \mathrm{~m}$ between plants. Three coffee rows interspersed among the tree species were fixed in the spacing between rows in a total of $13.6 \mathrm{~m}$ between the wooded rows.

The wood species canopy had their diameter measured by a rule (in meters), considering the radius of the distance of the canopy projection on the ground in relation to the tree shaft. 
The means of treatments were considered for the values of canopy diameter of wood species, as follows: for the year 2017, MoE1 (2.30 m), MoE2 (2.30 m), TeE1 $(1.70 \mathrm{~m})$, TeE2 $(2.33 \mathrm{~m})$, AcE1 (4.67 m), AcE2 (5.20 $\mathrm{m})$; and, for the year 2018, MoE1 (2.50 m), MoE2 (2.63 m), TeE1 (2.31 m), TeE2 (2.93 m), AcE1 (6.40m), AcE2 $(7.40 \mathrm{~m})$.

Coffee harvest was evaluated from the total detachment of fruit per plot, from six plants in each plot, that is, three plants located at 0.65, 1.30 and 1.95 $\mathrm{m}$ to the left, and three plants located at $0.65,1.30$ and $1.95 \mathrm{~m}$ to the right of the wood species, in the planting row. Subsequently, fruit harvested from the six plants were mixed, and a sampling of $4 \mathrm{~L}$ was taken per experimental plot. Such samplings were exposed to the sun until reaching the adequate moisture content, to proceed to their processing (between 11 and 12\%) with the constant inversion, so the drying process would homogenously take place. After coffee processing, the samples were weighed. The calculus for productivity conversion was then determined (sacks ha-1).

Coffee was harvested manually, selecting only the "cherry" fruit from eight plants, in each plot located at $0.65,1.30,1.95$, and $2.60 \mathrm{~m}$ to the left, and at $0.65,1.30,1.95$ and $2.60 \mathrm{~m}$ to the right of the wood species, to harvest $6 \mathrm{~L}$ from each plot. Immediately after harvesting, the coffee samples were sent to dry processing, which consisted of washing and eliminating malformed fruit. Subsequently, the fruit were taken to the suspended terrace, where they were dried in the sun, until reaching $12 \%$ moisture. In the next stage, the coffee samples were stored in Kraft paper bags, and covered by plastic bags in a cold chamber at $18^{\circ} \mathrm{C}$, for a period of 40 days, until the beginning of processing.

For sample processing, a portable processor DRC-2 n 307 (Pinhalense, São Paulo, SP, Brazil) was used and, successively, the samples were conditioned in plastic packages and sent for sensory analysis.

The sensory analysis was performed by three tasters (Q-graders) based on the methodology proposed by Lingle (2011), and the specialty coffee was characterized to not show any type of beverage defect and get minimum 80 points in the protocol, for the evaluation of specialty coffee of the Specialty Coffee Association of America (SCAA).

The treatment samples were identified with increasing natural numbers $(1,2,3,4,5,6,7,8,9,10$,
...), in order to hide treatment identification from the tasters.

The following seven attributes were evaluated: aroma, flavor, acidity, body, aftertaste, balance, or equilibrium, and overall score. Since the other attributes did not show any sensory defect, they were adopted as clean cup, presence of sweetness, and uniformity in all samples assigning, for such, score 10 (maximum). Based on the methodology proposed by Lingle (2011), coffee received scores from 0 to 100 , and coffee with a final score superior to 80 were classified as specialty.

The results of the sensory analysis may be presented through a sensory profile and are represented by "sensorgram" graphs, known as radar or spiderweb, enabling a better view of the sensory attributes (Sobreira et al., 2015) which, in the center of the image, represent the scale zero point, increasing the value from the center to the peripheral zone. The results of the scores for the analysis of sensory attributes were used from the average by three tasters (Q-graders).

From the approaches to the coffee nuances analyzed by the tasters (Q-graders), the method of content analysis was used (Bardin, 1977), which allowed of the quantification of the nuances from their word frequency, in order to grasp better knowledge about the sensory profile and the intensity of nuances of the studied treatments.

The attributes and their nuances were classified as follows: for flavor/aroma - 'caramel', 'brown', 'milk chocolate', 'chocolate', 'fruity', 'red fruits', 'citric', 'rapadura', 'molasses', or 'sweet'; for body - 'soft', 'full-bodied', 'dense', 'creamy', 'velvety', or 'silky'; for acidity - 'medium', 'alive'.

The values of productivity, sensory analysis, and sensory attributes were subjected to the analysis of variance using the statistical program Sisvar 4.3 (Ferreira, 2011). The average values were compared by the t-test, or by the Fisher's least significant difference test (LSD), at $5 \%$ probability.

\section{Results and Discussion}

The summary of the analysis of variance shows that productivity was significant over the years and, for the interaction of the factors, despite the influence of the year on the sensory analysis (Table 1).

Coffee tree shows a highlighted biennial behavior in the two harvesting years (2017 and 2018), corresponding 
to the $4^{\text {th }}$ and $5^{\text {th }}$ year of coffee harvesting (Table 2). This means that the presence of the wood species did not decrease the biennial behavior of the coffee crop in the first years of cultivation.

Table 1. Analysis of variance for productivity (sacks ha-1) and sensory analysis (final score) of arabica coffee (Coffea arabica) cultivated in monoculture or intercropped with the wood species African mahogany, teak, and pink cedar, at two spacings, in the 2017 and 2018 crop years, in the municipality of Lavras, in the state of Minas Gerais, Brazil.

\begin{tabular}{lccc}
\hline Source of variation & $\begin{array}{c}\text { Degree of } \\
\text { freedom }\end{array}$ & \multicolumn{2}{c}{ Mean Square } \\
\cline { 3 - 4 } & 3 & 89.53 & 1.44 \\
\hline Block & 6 & 249.01 & 1.86 \\
Treatment & 18 & 300.18 & 1.49 \\
Error 1 & 1 & $50,549.51^{* *}$ & $14.50^{*}$ \\
Year & 3 & 312.62 & 1.62 \\
Error 2 & 6 & $1,159.21^{*}$ & 1.60 \\
Treatment x year & 18 & 259.23 & 0.68 \\
Error 3 & & 25.10 & 1.46 \\
\hline CV1 (\%) & & 25.62 & 1.52 \\
CV2 (\%) & & 23.33 & 0.99 \\
CV3 (\%) & &
\end{tabular}

***Significant at $5 \%$ and $1 \%$, respectively; $\mathrm{CV}$, coefficient of variation. Treatments: MoE1, African mahogany (Khaya ivorensis), at 9.0x13.6 m; MoE2, African mahogany, at 18.0x13.6 m; TeE1, teak (Tectona grandis), at 9.0x13.6 m; TeE2, teak, at 18.0x13.6 m; AcE1, pink cedar (Acrocarpus fraxinifolius), at 9.0x13.6 m; AcE2, pink cedar, at 18.0x13.6 m; Mono, coffee (Coffea arabica) plants in monoculture.
Coffee productivity showed effects of intercropping, in the $5^{\text {th }}$ year of cultivation (Table 2). In 2017, the coffee plants cultivated in monoculture showed the highest productivity, differing significantly from the other treatments, except for MoE1, AcE1 and AcE2.

For 2018, coffee plants benefited from all species in intercropping, mainly with African mahogany, regardless of the spacing used. The continuity of high productivities was observed when coffee plants were intercropped with the species MoE1, in 2017 and 2018, and the lowest productivity values occurred when coffee trees were cultivated in the monoculture system.

It is important to emphasize that coffee plants intercropped in 2018 showed a greater productivity than coffee in monoculture, that is, the species in intercropping began to influence positively after 6 years of planting, decreasing the vulnerability of coffee plants to extreme climatic events. Coffee intercropped with tree species shows better results for productivity than coffee cultivated in the monoculture system (Moreira et al., 2018).

Intercropping is an important factor for the attribution of the producer, as this system not only provides the gain with the crop of interest, but also the economic wealth by the option of adopting noble wood species, especially when it comes to species as African mahogany, with a high added value.

Table 2. Productivity and sensory analysis (final score) of arabica coffee (Coffea arabica) cultivated in monoculture or intercropped with the wood species African mahogany, teak and pink cedar, at two spacings, in the 2017 and 2018 crop years, in the municipality of Lavras, in the state of Minas Gerais, Brazil ${ }^{(1)}$.

\begin{tabular}{|c|c|c|c|c|}
\hline \multirow[t]{2}{*}{ Treatment } & \multicolumn{2}{|c|}{ Productivity $\left(\right.$ sacks ha $\left.^{-1}\right)$} & \multicolumn{2}{|c|}{ Sensory analysis } \\
\hline & 2017 & 2018 & 2017 & 2018 \\
\hline MoE1 & $44.21 \mathrm{abB}$ & $109.47 \mathrm{abA}$ & $83.37 \mathrm{aB}$ & $85.25 \mathrm{aA}$ \\
\hline MoE2 & $24.34 \mathrm{bB}$ & $125.34 \mathrm{aA}$ & $83.50 \mathrm{aB}$ & $85.00 \mathrm{aA}$ \\
\hline TeE1 & $29.91 \mathrm{bB}$ & $98.22 \mathrm{bcA}$ & $83.12 \mathrm{aB}$ & $85.12 \mathrm{aA}$ \\
\hline TeE2 & $30.43 \mathrm{bB}$ & $95.57 \mathrm{bcA}$ & $83.75 \mathrm{aB}$ & $85.12 \mathrm{aA}$ \\
\hline AcE1 & 44.41abB & $87.73 \mathrm{bcA}$ & $83.87 \mathrm{aA}$ & $83.50 \mathrm{bA}$ \\
\hline AcE2 & $44.21 \mathrm{abB}$ & $93.87 \mathrm{bcA}$ & $83.00 \mathrm{aA}$ & $83.37 \mathrm{bA}$ \\
\hline Mono & $58.25 \mathrm{aB}$ & $83.19 \mathrm{cA}$ & $83.25 \mathrm{aA}$ & $83.62 \mathrm{bA}$ \\
\hline Média & 39.40 & 99.05 & 83.40 & 84.42 \\
\hline CV1(\%) & \multicolumn{2}{|c|}{25.10} & \multicolumn{2}{|c|}{1.46} \\
\hline CV2(\%) & \multicolumn{2}{|c|}{25.62} & \multicolumn{2}{|c|}{1.52} \\
\hline $\mathrm{CV} 3(\%)$ & \multicolumn{2}{|c|}{23.33} & \multicolumn{2}{|c|}{0.99} \\
\hline
\end{tabular}

${ }^{(1)}$ Means followed by equal letters, uppercases in the rows and lowercases in the columns, do not differ by the t-test (LSD), at $5 \%$ probability. CV, coefficient of variation. Treatments: MoE1, African mahogany (Khaya ivorensis), at 9.0x13.6 m; MoE2, African mahogany, at 18.0x13.6 m; TeE1, teak (Tectona grandis), at 9.0x13.6 m; TeE2, teak, at 18.0x13.6 m; AcE1, pink cedar (Acrocarpus fraxinifolius), at 9.0x13.6 m; AcE2, pink cedar, at 18.0x13.6 $\mathrm{m}$; Mono, coffee (Coffea arabica) plants in monoculture. 
Irrigated coffee planted at $0.7 \times 3.5 \mathrm{~m}$ spacing, intercropped with macadamia tree species in $4.9 \times 10.5 \mathrm{~m}$ spacing, showed increased coffee productivity in $60 \%$ and $133 \%$ for macadamia, in comparison with monoculture systems (Arantes, 2017). The positive increase of productivity depends on the interaction between the intercropped species

However, the different spacing between wood species is directly related to shading levels, competitiveness, and allelopathy of different tree species with coffee plants. These aspects can interfere with the yield potential and with the quality of the coffee fruit.

Regarding the averages for the sensory variable analysis, there were no significant differences between the treatments in 2017 (Table 2). However, in 2018, beverage quality scores were higher for coffee beans from plants intercropped with African mahogany and teak plants, regardless of spacing. In general, all treatments showed high scores by the sensory analysis and, for values above 83 points, coffee is considered specialty. The highest scores in the sensory analysis were obtained in the year of high harvest, which shows the beneficial influence of intercropping on coffee, mainly when coffee was intercropped with African mahogany and teak, under moderate shading of 2.31-2.93 m canopy.

According to Steiman et al. (2011), the advantages of moderate shading are mainly explained by the reduction of induced heat stress and the extension of coffee fruit maturation period, providing favorable productivity and coffee beans with greater quality with intercropping. The agricultural practice of intercropping has gained attention due to the increase of the quality of ripe "cherry" fruit of coffee trees (Prado et al., 2018). The favorable microclimate formed by moderate shading leads to a delay of fruit ripening, resulting in a longer period of development that results in larger beans (Bote \& Vos, 2017). Larger beans with organoleptic characteristics show the quality of the beverage; it also allows to obtain greater financial gains for the producer due to the value added by quality, as well as extra gains with noble wood species.

In this context, for a coffee to be considered specialty, it is essential that it has a balance in sensory attributes (Ribeiro et al., 2017). Thus, to determine the quality potential of coffee intercropped with wood species, or of coffee cultivated in monoculture, the use of a final score of sensory analysis is not sufficient to meet the most diverse tastes of customers. It is necessary to explore the behavior of coffee sensory attributes (Figure 1), and the nuances (Figure 2) that are identified by the tasters, which turns coffee more singular and unique.

Aroma was significant over the years, together with acidity, body, and overall score, for the interaction of the factors, although flavor, balance, and aftertaste were not influenced by the treatments and years studied, according to the analysis of variance (Table 3).

Coffee intercropped with African mahogany and teak, regardless of spacing, achieved the highest scores of sensory attributes in 2018 when compared with 2017 (Figure 1). Attributes with higher scores are located on the most extreme lines of the graph and with the highest homogeneity of scores between attributes.

The body sensory attribute reached score 8.0 (Figures 1 A, B, D, and E) in 2017, and in 2018 (Figure $1 \mathrm{~A}, \mathrm{~B}, \mathrm{C}$, and $\mathrm{D}$ ); this attribute was responsible for texture and sensation in the mouth, which are directly related to total compounds, fat content, or fatty acids (Gloess et al., 2013). A positive contribution of the body sensory attribute is reported with the increase of the quality of arabica coffee, contributing to the highest sensory scores, according to Figueiredo et al. (2015).

Higher acidity scores were obtained in coffee intercropped with MoE1, TeE1 and TeE2 (Figures $1 \mathrm{~A}, \mathrm{C}$, and D) in 2018. The highest acidity results are observed in the highest-quality coffee (Angnoletti, 2015).

The overall evaluation of the coffee beverage is very because it is the last reading of its sensory attributes, reflecting its originality. The obtained scores were higher in 2018, mainly for coffee in combination with MoE1 (7.90), MoE2 (7.90), and TeE1 (7.90), respectively (Figure $1 \mathrm{~A}, \mathrm{~B}, \mathrm{C}$, and D), and the lowest scores were given to coffee intercropped with AcE2 (7.50) (Figure 1 F) and to coffee in Mono (7.30) (Figure $1 \mathrm{G}$ ).

Coffee intercropping with wood species that show moderate shade was favorable, according to the crown diameters of MoE1 $(2.50 \mathrm{~m}), \mathrm{MoE} 2$ (2.63 $\mathrm{m}), \mathrm{TeE} 1(2.31 \mathrm{~m})$, and TeE2 $(2.93 \mathrm{~m})$ in relation to the crown of pink cedar [AcE1 $(6.40 \mathrm{~m})$ and AcE2 $(7.40 \mathrm{~m})]$. Intercropping with plants of a great shade (Silveira et al., 2016) can cause greener coffee fruit, with greater roughness, and unpleasant flavor (Vaast et al., 2006). Therefore, greater shading levels of trees can harm intercropped coffee plants, causing losses to the beverage quality due to the lower accumulation of 
A

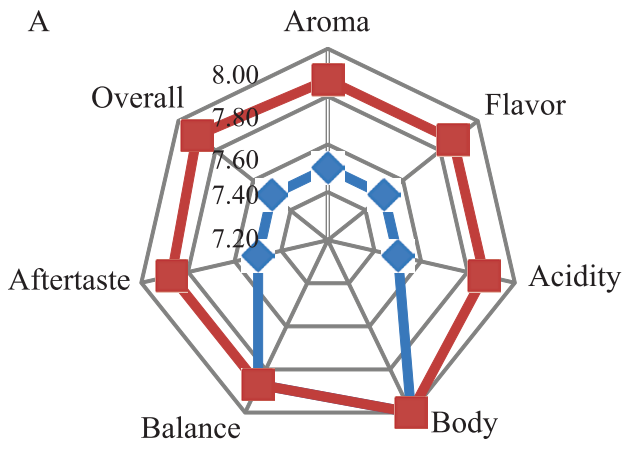

C

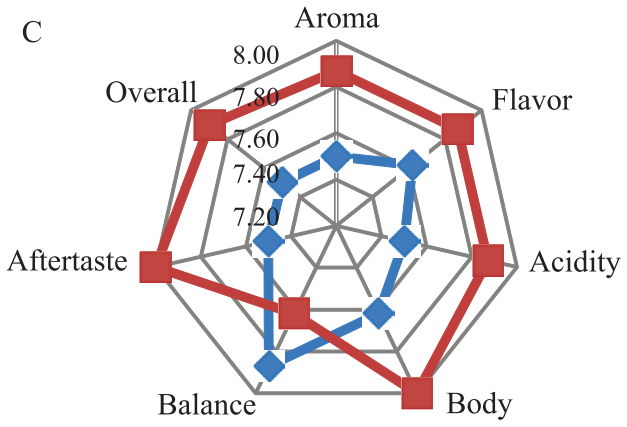

$\mathrm{E}$

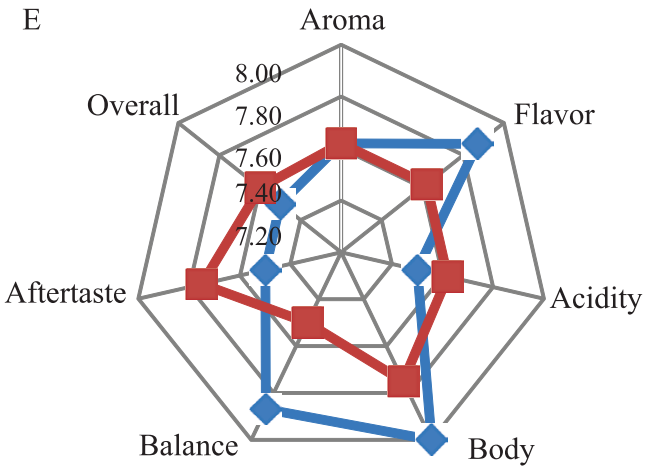

G

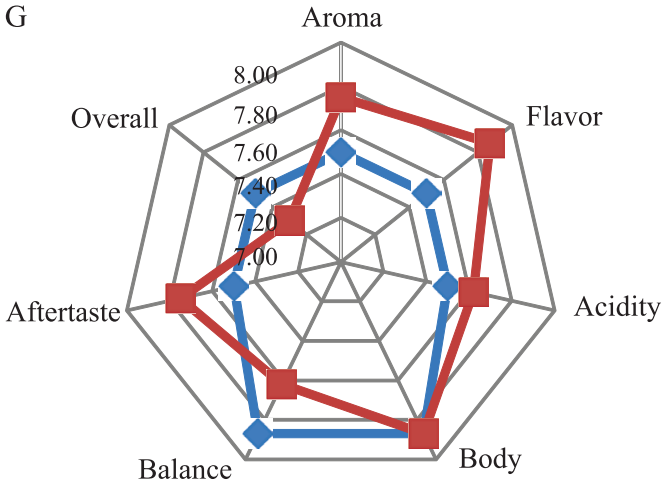

B

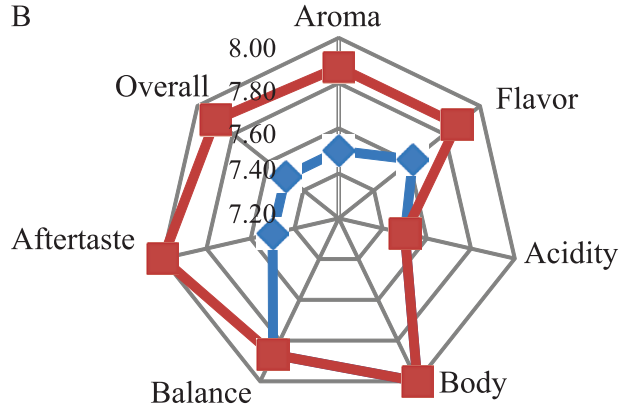

D

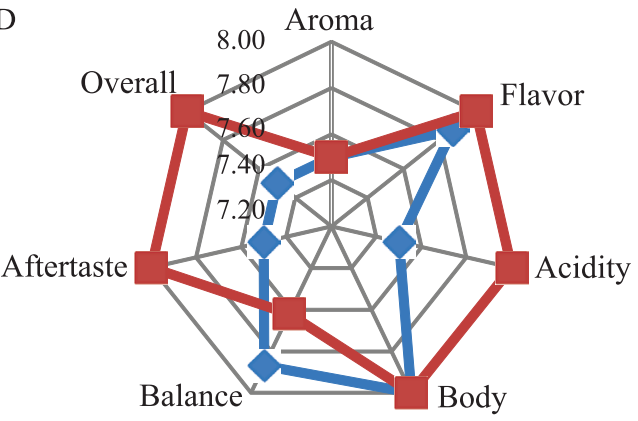

$\mathrm{F}$

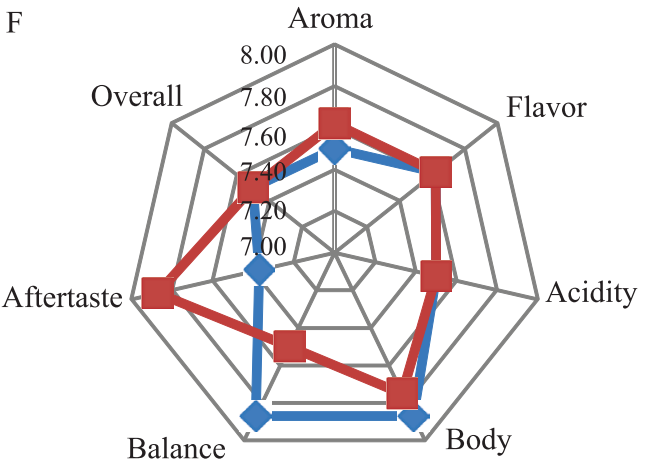

Figure 1. Sensorgram for the sensory attributes of beverage of arabica coffee (Coffea arabica) in monoculture, or intercropped with wood species, in two spacings, in the 2017 and 2018 crop years, in the municipality of Lavras, in the state of Minas Gerais, Brazil. Treatments: MoE1, African mahogany (Khaya ivorensis), at 9.0x13.6 m (A); MoE2, African mahogany, at 18.0x13.6 m (B); TeE1, teak (Tectona grandis), at 9.0x13.6 m (C); TeE2, teak, at 18.0x13.6 m (D); AcE1, pink cedar (Acrocarpus fraxinifolius), at 9.0x13.6 m (E); AcE2, pink cedar, at 18.0x13.6 m (F); Mono, coffee (Coffea arabica) plants in monoculture $(\mathrm{G})$. 

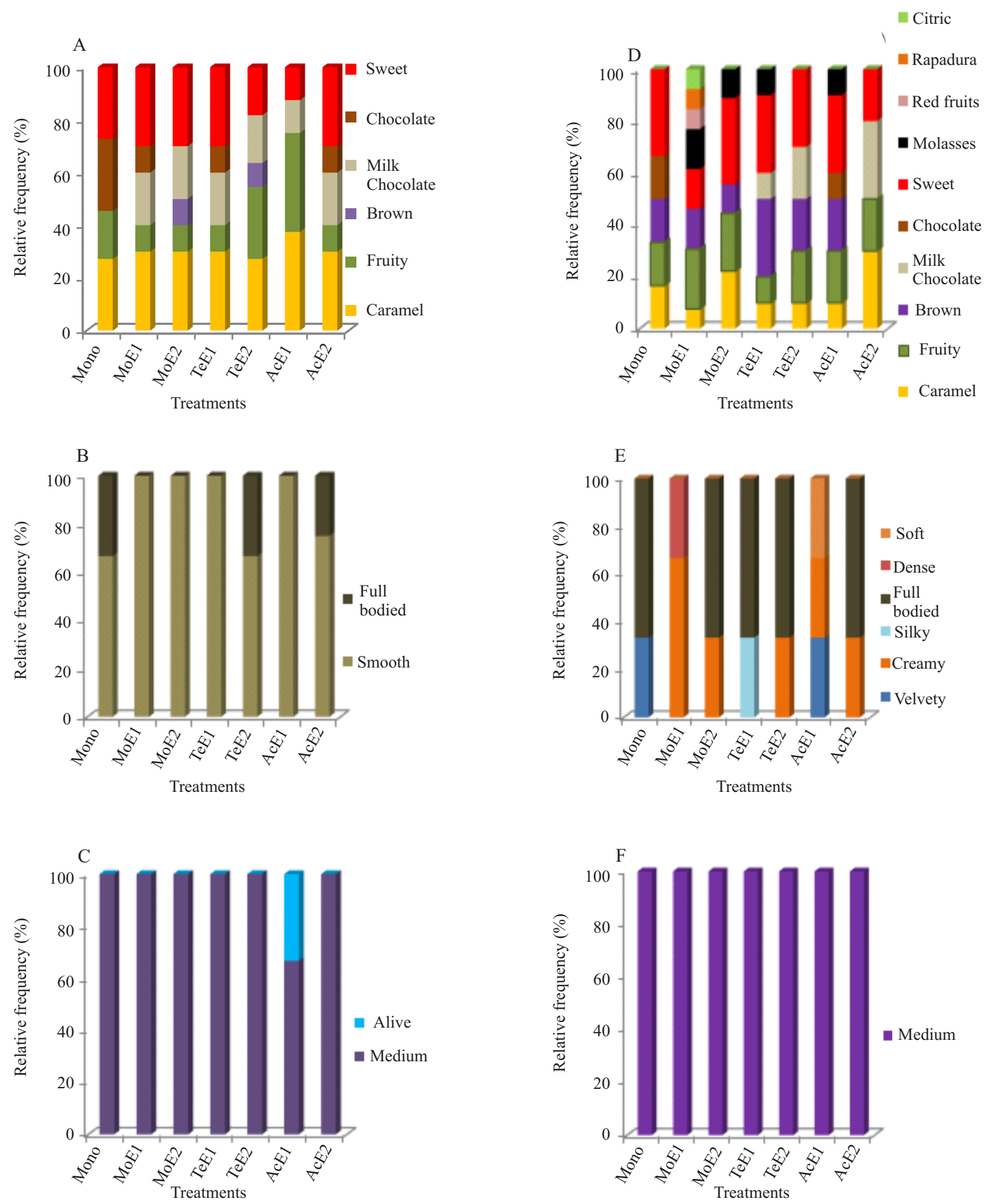

Figure 2. Relative frequency of the following nuances: in the 2017 harvest, flavor/aroma (A), body (B), and acidity (C); and, in the 2018 harvest, flavor/aroma (D), body (E), and acidity (F). Treatments of arabica coffee in monoculture or intercropped with wood species in two spacings: Mono, arabica coffee (Coffea arabica) tree in monoculture; MoE1, African mahogany (Khaya ivorensis), at 9.0x13.6 m; MoE2, African mahogany, at 18.0x13.6 m; TeE1, teak (Tectona grandis), at 9.0x13.6 m; TeE2, teak, at 18.0x13.6 m; AcE1, pink cedar (Acrocarpus fraxinifolius), at 9.0x13.6 m; AcE2, pink cedar, at 18.0x13.6 m; Mono, coffee (Coffea arabica) plants in monoculture. 
photoassimilates (Ramos et al., 2017). However, it is evident that the microclimate associated with a given tree species will be responsible for manifesting the intensity of the different attributes. It may result in an increase of the potential of a specialty beverage.

The study of nuances helps differentiate the quality and intensity of the final scores and is able to better attend the niche markets Sobreira et al. (2015). From the attributes, the associated nuances were transformed into frequency based on the number of mentions made by the tasters, from the 2017 and 2018 harvest. This is an exploration of nuances by the qualitative method, which consists of grouping words based on frequencies (Bardin, 1977).

The frequency of words produced by "Q-grader" panelists shows the nuances of coffee for flavor/aroma, body, and acidity, within each treatment of the 2017 and 2018 harvests (Figure 2). The noticeable nuance in 2017 for flavor/aroma (Figure $2 \mathrm{~A}$ ) was the 'caramel' word, common for all treatments. The nuances of flavor/ aroma for coffee, in association with the species MoE1 and MoE2, showed the same frequencies for 'caramel' (32\%), 'fruity' (10\%), 'milk chocolate' (18\%), and 'sweet' (27\%). Coffee intercropped with TeE1 and TeE2 showed the same nuances only for 'milk chocolate' $(18 \%)$. The highest frequency for coffee intercropped with TeE1 was for the words 'caramel' (32\%) and 'sweet' (28\%), and, for the intercropping with TeE2, the highest word frequency was for 'fruity' (27\%).
Coffee intercropped with pink cedar showed different nuances and was dependent on spacing, that is, when in the presence of AcE1, the same word frequencies (38\%) were observed for 'caramel' and 'fruity', and, for AcE2, the word frequency was 31\% for both 'caramel' and 'sweet'.

As pink cedar is a species of fast vegetative growth (Silveira et al., 2016), with a large canopy, its influence on coffee trees causes an interference with spacing. Coffee trees intercropped with AcE1 result in 'caramel', 'fruity', 'chocolate', and 'sweet' flavors, with lower amounts of nuances.

For the body sensory attribute, all treatments showed the frequency of 'soft' nuances. However, the 'fullbodied' nuance appeared only for the Mono (32\%), TeE2 (32\%), and AcE2 (23\%) treatments. For acidity, the nuances remained at 'medium' acidity, except for AcE1, with 'alive' acidity (33\%).

In the 2018 harvest, flavor/aroma and body acquired more nuance variations (Figure $2 \mathrm{D}$ and $\mathrm{E}$ ), which may have contributed to the higher scores of the sensory analysis. There was more distinction of flavors among the treatments; however, the common flavor/aroma is 'caramel', 'fruity', and 'sweet'. In a study on the quality of coffee, Scholz et al. (2013) also observed 'caramel' and 'fruity' as the most frequent terms

It appears that coffee intercropped with MoE1 showed the greatest diversity of nuances (Figure $2 \mathrm{D}$ ), such as 'caramel', 'fruity', 'brown', 'sweet', 'molasses',

Table 3. Analysis of variance of the sensory attributes of arabica coffee (Coffea arabica) intercropped cultivated in monoculture or intercropped with the wood species African mahogany, teak and pink cedar, at two spacings, in the 2017 and 2018 crop years, in the municipality of Lavras, in the state of Minas Gerais, Brazil.

\begin{tabular}{|c|c|c|c|c|c|c|c|c|}
\hline \multirow{2}{*}{$\begin{array}{l}\text { Source of } \\
\text { variation }\end{array}$} & \multirow{2}{*}{$\begin{array}{c}\text { Degrees of } \\
\text { Freedom }\end{array}$} & \multicolumn{7}{|c|}{ Mean square of sensory attributes } \\
\hline & & Aroma & Flavor & Acidity & Body & Balance & Aftertaste & Overall \\
\hline Block & 3 & 0.05 & 0.01 & 0.03 & 0.00 & 0.01 & 0.12 & $0.05^{*}$ \\
\hline Treatment & 6 & 0.05 & 0.07 & $0.08 * *$ & 0.06 & 0.06 & 0.02 & $0.10 * *$ \\
\hline Error 1 & 18 & 0.07 & 0.06 & 0.01 & 0.03 & 0.04 & 0.08 & 0.01 \\
\hline Year & 1 & $0.44 *$ & 0.36 & $0.64 *$ & 0.00 & 0.04 & 0.00 & $0.75^{*}$ \\
\hline Error 2 & 3 & 0.02 & 0.05 & 0.03 & 0.03 & 0.05 & 0.04 & 0.05 \\
\hline Treatment x Year & 6 & 0.07 & 0.10 & $0.08 * *$ & $0.07 *$ & 0.04 & 0.02 & $0.10^{* *}$ \\
\hline Error 3 & 18 & 0.05 & 0.04 & 0.01 & 0.02 & 0.03 & 0.03 & 0.01 \\
\hline CV1 (\%) & & 3.56 & 3.20 & 1.60 & 2.44 & 2.74 & 3.78 & 1.73 \\
\hline CV2 (\%) & & 2.27 & 2.95 & 2.48 & 2.39 & 3.06 & 2.54 & 3.00 \\
\hline CV3 (\%) & & 3.15 & 2.64 & 1.60 & 2.01 & 2.51 & 2.31 & 1.73 \\
\hline
\end{tabular}

***Significant at 5\% and 1\%, respectively; CV, coefficient of variation. Treatments: MoE1, African mahogany (Khaya ivorensis), at 9.0x13.6 m; MoE2, African mahogany, at 18.0x13.6 m; TeE1, teak (Tectona grandis), at 9.0x13.6 m; TeE2, teak, at 18.0x13.6 m; AcE1, pink cedar (Acrocarpus fraxinifolius), at 9.0x13.6 m; AcE2, pink cedar, at 18.0x13.6 m; Mono, coffee (Coffea arabica) plants in monoculture. 
'red fruits', 'brown sugar', and 'citrus', conferring peculiarities to coffee.

In 2018, all body sensory attributes showed variations in a great number of nuances (Figure $2 \mathrm{E}$ ), when compared to 2017 (Figure 2 B). The attributes 'full-bodied' and 'creamy' were predominant among the treatments, they did not appear only for MoE1 and AcE1. The 'creamy' nuance did not appear for monoculture treatments and for TeE1 (Figure $2 \mathrm{E}$ ).

The same frequency (65\%) of 'full-body' was also observed for monoculture, MoE2, and TeE1.Higher amounts of flavor/aroma and body nuances were observed in 2018 than in 2017. Average acidity showed the high frequencies for the two studied harvests.

The sensory quality of coffee is strongly influenced by environmental factors because of their impact on the origin of the chemical compounds present in the raw bean (Ribeiro et al., 2016). Profiles with different nuances, mainly in flavors, promote a wider reach of consumers, who have different requirements for the pleasure of consuming the coffee beverage. However, the scientific literature on nuances of specialty coffee is very scarce, so that further research is necessary to argue more on the subject.

\section{Conclusions}

1. Arabica coffee (Coffea arabica) shows higher productivity when intercropped with African mahogany (Khaya ivorensis), regardless of spacing between these species, as well as higher sensory quality, both in the 2018 harvest.

2 . The sensory attributes acidity, body, nuances, and overall characteristics are influenced by treatments and year of harvest.

3. To better distinguish coffee quality and meet market demands, the content analyses of sensory attributes can be applied to coffee both from monoculture and intercropping systems.

\section{Acknowledgments}

To Conselho Nacional de Desenvolvimento Científico e Tecnológico (CNPq, GRC-304449/20180), to Coordenação de Aperfeiçoamento de Pessoal de Nível Superior (Capes, Code 001, 02.13.02.049.00.04), to Empresa de Pesquisa Agropecuária de Minas Gerais (Epamig, 02.10.02.049.00.04), and to Consórcio Brasileiro de Pesquisa e Desenvolvimento do Café, for financial support; and to Fazenda da Lagoa of the NKG group (Gruppe Kaffee Neumann), for providing the facilities and support for carrying out the experiment.

\section{References}

ANGNOLETTI, B.Z. Avaliação das propriedades físicoquímicas de café arábica (Coffea arabica) e conilon (Coffea canephora) classificados quanto à qualidade da bebida. 2015. Dissertação (Mestrado) - Universidade Federal do Espírito Santo, Alegre.

ARANTES, J.T. Consórcio com a macadâmia protege o café e aumenta sua produtividade. 2017. Available at: $<\mathrm{http}$ ://agencia. fapesp.br/consorcio-com-a-macadamia-protege-o-cafe-eaumenta-sua-produtividade/24643/>. Accessed on: Jan. 232019.

ARAÚJO, A.V.; PARTELLI, F.L.; OLIVEIRA, M.G; PEZZOPANE, J.R.M.; FALQUETO, A.R.; CAVATTE, P.C. Microclimatic and vegetative growth in coffee and banana intercrop. Coffee Science, v.10, p.214-222, 2015. DOI: https://doi.org/10.25186/cs.v10i2.856.

BARDIN, L. Análise de conteúdo. Lisboa: Edições 70, 1977.

BOTE, A.D.; VOS, J. Tree management and environmental conditions affect coffe (Coffea arabica L.) bean quality. NJAS Wageningen Journal of Life Sciences, v.83, p.39-46, 2017. DOI: https://doi.org/10.1016/j.njas.2017.09.002.

CUNHA, D.A. da; COELHO, A.B.; FÉRES, J.G. Irrigation as an adaptive strategy to climate change: an economic perspective on Brazilian agriculture. Environment and Development Economics, v.20, p.57-79, 2015. DOI: https://doi.org/10.1017/ S1355770X14000102.

FERREIRA, D.F. Sisvar: a computer statistical analysis system. Ciência e Agrotecnologia, v.35, p.1039-1042, 2011. DOI: https://doi.org/10.1590/s1413-70542011000600001.

FIGUEIREDO, L.P.; BORÉM, F.M.; RIBEIRO, F.C.; GIOMO, G.S.; TAVEIRA, J.H. da S.; MALTA, M.R. Fatty acid profiles and parameters of quality of specialty coffees produced in different Brazilian regions. African Journal of Agricultural Research, v.10, p.3484-3493, 2015. DOI: https://doi.org/10.5897/ ajar2015.9697.

GLOESS, A.N.; SCHÖNBÄCHLER, B.; KLOPPROGGE, B.; D'AMBROSIO, L.; CHATELAIN, K.; BONGARTZ, A.; STRITTMATTER, A.; RAST, M.; YERETZIAN, C. Comparison of nine common coffee extraction methods: instrumental and sensory analysis. European Food Research and Technology, v.236, p.607-627, 2013. DOI: https://doi.org/10.1007/s00217-0131917-x.

LINGLE, T.R. The coffee cupper's handbook: a systematic guide to the sensory evaluation of coffee's flavor. Long Beach: Specialty Coffee Association of America, 2011. 66p.

MOREIRA, S.L.S.; PIRES, C.V.; MARCATTI, G.E.; SANTOS, R.H.S.; IMBUZEIRO, H.M.A.; FERNANDES, R.B.A. Intercropping of coffee with the palm tree, macauba, can mitigate climate change effects. Agricultural and Forest Meteorology, 
v.256-257, p.379-390, 2018. DOI: https://doi.org/10.1016/j. agrformet.2018.03.026.

PRADO, S.G.; COLLAZO, J.A.; IRWIN, R.E. Resurgence of specialized shade coffee cultivation: effects on pollination services and quality of coffee production. Agriculture, Ecosystems and Environment, v.265, p.567-575, 2018. DOI: https://doi.org/10.1016/j.agee.2018.07.002.

RAMOS, P.J.; PRIETO, F.A.; MONTOYA, E.C.; OLIVEROS, C.E. Automatic fruit count on coffee branches using computer vision. Computers and Electronics in Agriculture, v.137, p.922, 2017. DOI: DOI: https://doi.org/10.1016/j.compag.2017.03.010.

RIBEIRO, D.E.; BOREM, F.M.; CIRILLO, M.A.; PRADO, M.V.B.; FERRAZ, V.P.; ALVES, H.M.R.; TAVEIRA, J.H. da $\mathrm{S}$. Interaction of genotype, environment and processing in the chemical composition expression and sensorial quality of Arabica coffee. African Journal of Agricultural Research, v.11, p.24122422, 2016. DOI: https://doi.org/10.5897/ajar2016.10832.

RIBEIRO, L.S. RIBEIRO, D.E.; EVANGELISTA, S.R.; MIGUEL, M.G. da C.P.; PINHEIRO, A.C.M.; BORÉM, F.M.; SCHWAN, R.F. Controlled fermentation of semi-dry coffee (Coffea arabica) using starter cultures: a sensory perspective. Food Science \& Technology, v.82, p.32-38, 2017. DOI: https://doi.org/10.1016/j. lwt.2017.04.008.

SANTOS, H.G. dos; JACOMINE, P.K.T.; ANJOS, L.H.C. dos; OLIVEIRA, V.Á. de; LUMBRERAS, J.F.; COELHO, M.R.; ALMEIDA, J.A. de; ARAÚJO FILHO, J.C. de; OLIVEIRA, J.B. de; CUNHA, T.J.F. Sistema brasileiro de classificação de solos. 5.ed. rev. e ampl. Brasília: Embrapa, 2018.

SCHEMBERGUE, A.; CUNHA, D.A. da; CARLOS, S. de M.; PIRES, M.V.; FARIA, R.M. Sistemas agroflorestais como estratégia de adaptação aos desafios das mudanças climáticas no Brasil. Revista de Economia e Sociologia Rural, v.55, p.9-30, 2017. DOI: https://doi.org/10.1590/1234-56781806-94790550101.

SCHOLZ, M.B. dos S.; SILVA, J.V.N. da.; FIGUEIREDO, V.R.G. de.; KITZBERGER, C.S.G. Sensory attributes and physicochemical characteristics of the coffee beverage from the IAPAR cultivars. Coffee Science, v.8, p.6-16, 2013.
SILVEIRA, H.R. de O.; SANTOS, M. de O.; SILVA, V.A.; VENTURIN, R.P.; VOLPATO, M.M.L.; DANTAS, M.F.; CARVALHO, G.R.; SETOTAW, T.A.; MOREIRA, F.C.; BARBOSA, J.P.R.A.D.; RESENDE, M.L.V. de. Impactos da deficiência hídrica nas respostas ecofisiológicas e espectrais do cafeeiro consorciado com espécies madeireiras. Coffee Science, v.11, p.318-329, 2016.

SOBREIRA, F.M.; OLIVEIRA, A.C.B. de; PEREIRA, A.A.; SOBREIRA, M.F.C.; SAKYIAMA, N.S. Sensory quality of arabica coffee (Coffea arabica) genealogic groups using the sensogram and content analysis. Australian Journal of Crop Science, v.9, p.486-493, 2015.

SOUZA, T. da S. de; ALMEIDA, R.N.; BERILLI, S. da. S. Effect of shading on the drink quality of conilon coffee in intercrop systems. Revista Brasileirade Ciências Agrárias, v.14, e5782, 2019. DOI: https://doi.org/10.5039/agraria.v14i4a5782.

STEIMAN, S.; IDOL, T.; BITTENBENDER, H.C.; GAUTZ, L. Shade coffee in Hawai'i: exploring some aspects of quality, growth, yield, and nutrition. Scientia Horticultural, v.128, p.152158, 2011. DOI: https://doi.org/10.1016/j.scienta.2011.01.011.

SUATUNCE CUNUHAY, P.; DÍAZ CORONEL, G.; GARCÍA CRUZATTY, L. Evaluación de cuatro especies forestales asociadas con café (Coffea arabica L.) y en monocultivo en el litoral Ecuatoriano. Ciencia y Tecnología, v.2, p.29-34, 2009. DOI: https://doi.org/10.18779/cyt.v2i2.38.

VAAST, P.; BERTRAND, B.; PERRIOT, J.-J.; GUYOT, B.; GÉNARD, M. Fruit thinning and shade improve bean characteristics and beverage quality of coffee (Coffea arabica L.) under optimal conditions. Jornal of the Science of Food and Agriculture, v.86, p.197-204, 2006. DOI: https://doi.org/10.1002/ jsfa.2338.

VALENCIA, V.; NAEEM, S.; GARCÍA-BARRIOS, L.; WEST, P.; STERLING, E.J. Conservation of tree species of late succession and conservation concern in coffee agroforestry systems. Agriculture, Ecosystems and Environment, v.219, p.32-41, 2016. DOI: https://doi.org/10.1016/j.agee.2015.12.004. 